\title{
Prosecuting international crimes at the International Criminal Court: is there a coherent and comprehensive prosecution strategy?
}

\author{
Kai Ambos • Ignaz Stegmiller
}

Published online: 19 January 2013

(C) The Author(s) 2013. This article is published with open access at Springerlink.com

\begin{abstract}
The authors analyze the so far published selection and strategy papers of the Office of the Prosecutor ("OTP”) of the International Criminal Court ("ICC”) with a view to their consistency, coherence and comprehensiveness. Given the high number of communications and referrals to the ICC a focused strategy setting out the criteria for situation and case selection and prioritization should be one of the priorities of the Prosecutor. Thus far the Office has developed a strategic framework guided by four fundamental principles: focused investigations, positive complementarity, the interests of the victims and the impact of the OTP's work. These four principles are critically evaluated by the authors in light of the ICC Statute and existing case law. In particular the positive complementarity approach, focusing on the cooperation with national jurisdictions and enhancing their own capacity to prosecute, is to be welcomed and reflects a realistic prosecutorial policy approach. The cooperation between the OTP and Germany in the prosecution of the leadership of the FDLR is a good case in point. Only such a close interaction with national jurisdictions enables the ICC to contribute to the further closing of the impunity gap. Yet, the OTP must still more precisely define its position with regard to the criteria used for the selection of situations and cases. Thus, a priority for the new Prosecutor should be the drafting of a more precise and comprehensive strategy, integrating the already existing policy and strategy papers as well as drawing on lessons learned.
\end{abstract}

The opinions expressed in this paper are made in a personal capacity.

An earlier version was mistakenly published in Volume 58, Issue 4, under doi:10.1007/s10611-0129384-z.

\footnotetext{
K. Ambos $(\bowtie)$

Comparative Law and International Criminal Law, Georg-August Universität Göttingen,

Göttingen, Germany

e-mail: kambos@gwdg.de

K. Ambos

District Court (Landgericht) Göttingen, Göttingen, Germany

I. Stegmiller

German Agency for International Cooperation GIZ, Phnom Penh, Cambodia

e-mail: ignaz.stegmiller@gmx.de
} 


\section{Introduction}

The selection and prioritization of cases to be prosecuted before the ICC, while necessary and legitimate given the existing capacity constraints and the goals of the Court to prosecute the "most serious crimes" of the "most responsible", runs the risk to bring the Court into disrepute if not done properly, i.e., in a transparent and rational way. The selection of defendants is complex and essentially preceded by two main steps: first, it has to be distinguished between the primary selection of situations ("locations" where possible ICC crimes have taken place) and the subsequent extraction of cases (including one or more perpetrators) from these situations (cf. OTP Regulations 34 et seq.). Further, one must distinguish between the selection process of the Office of the Prosecutor (OTP) and the - lately very much criticised - referral procedure of the UN Security Council (SC) which so far has only been invoked with regard to Non-State Parties of the ICC (Darfur, Sudan and the Libyan Arab Jamahiriya). The ICC can normally exercise jurisdiction only in cases where the accused is a national of a State Party or when the alleged crime took place on the territory of a State Party. ${ }^{1}$ Other scenarios can be referred to the ICC by the SC. The decision whether to refer a situation in a Non-State Party to the ICC - or not to refer it and thus not to trigger ICC jurisdiction - depends on eminently political considerations of the SC. The ICC has no bearing on this decision and may only, once a situation is referred to it, analyse the situation in light of its statutory criteria and decide whether or not to open a (formal) investigation.

This paper focuses primarily on the selection of cases, a core issue for prosecutorial coherence; yet it does not pretend to cover all questions that might arise during the complex selection process. As to this process different approaches are possible. One may choose cases on a first come, first serve basis, or according to the greatest ease of access to evidence, or based on formal criteria (Bergsmo, 2010, at 9 [8]). The last approach is an essential innovation of the ICC, where the OTP uses certain legal and policy criteria to rank cases in a coherent manner. The problem of selecting situations and cases was less important for other international(ized) tribunals, such as the International Criminal Tribunal for Rwanda (ICTR) and the International Criminal Tribunal for the Former Yugoslavia (ICTY), because their jurisdictional reach is far more limited in territorial and temporal terms in the first place. In other words, the ad hoc tribunals did not have to select their "situations" as these were already defined in their Statutes. The ICTR and ICTY could directly start off, selecting appropriate cases for investigation and prosecution. The ICC can, in turn, theoretically act on a universal scale. For these reasons, more difficult choices have to be made and selectivity plays an important role. The function of the court, and its legitimacy, stand and fall with such decisions. The authors will therefore concentrate on the ICC's selection strategy. As will be seen below, the OTP initiated a process of public consultations to develop consistent selection criteria, quite different from earlier international criminal tribunals that did not address the issue in a public and transparent way. However, the debate on selection at the ICC is only just beginning. Many questions, such as the binding nature of those selection criteria and the exact choice of criteria, still remain and require further reflection and debate.

\footnotetext{
${ }^{1}$ Note that a declaration according to article 12 (3) ICC Statute triggers the ICC's jurisdiction and, in this sense, gives also rise to preliminary examinations. It will then be dealt with, however, under article 15 ICC Statute.
} 
This paper focuses on the OTP approach laid down in its Prosecutorial Strategy (see Selection strategy at the ICC (OTP) section) and examines the four fundamental principles: focused investigations (see Focused investigations section), positive complementarity (see Positive complementarity section), interests of the victims (see Addressing the interests of victims section) and the impact of the OTP's work (see Maximising the impact: developing a coherent strategy at the ICC section). Only by means of certain improvements can the OTP's impact be maximised, primarily continued transparency is necessary; the publication of interim reports and the integration of all policy and strategy papers into one coherent strategy as a permanent model for case selection in the whole field of international criminal justice.

\section{Selection strategy at the ICC (OTP)}

During the last years the OTP has consistently addressed key points of its selection strategy in several papers, albeit failing to develop a comprehensive approach. The Office dealt with the different problems as they arose publishing the respective policy and strategy papers outlined below.

\section{Identifying sources}

According to OTP Regulation 14 (see Regulations of the OTP, 2009 [47]), the OTP, as already mentioned above, can make use of policy papers that reflect the key principles and criteria. Four fundamental principles lie at the core of the Strategy: (i) positive complementarity, (ii) focused investigations and prosecutions, (iii) addressing the interests of victims, and (iv) maximizing the impact of the Office's work (Prosecutorial Strategy, 2009-2012, at 4-7 [45]).

In accordance with OTP Regulation 14, the OTP have made various papers available to the public. First, key strategic issues are laid down in two strategy papers: (i) the Strategy 2006-2009 (Report on Prosecutorial Strategy, 2006 [48]), ${ }^{2}$ and (ii) the Strategy 2009-2012 (Prosecutorial Strategy, 2010 [45]). Second, several policy papers of the OTP clarify other key issues, such as the "interests of justice", victim's participation and preliminary examinations. The latest draft version on preliminary examinations (Draft Policy Paper on Preliminary Examinations, 2010 [15]) will be further examined below. More policy papers on topics such as positive complementarity and case selection are in the consultation process and will be published in the future.

\section{Lack of a comprehensive, overall strategy}

The OTP uses the terms "policy" and "strategy" indiscriminately. The strategy papers cover certain time periods (2006-2009 and 2009-2012) and clarify the strategic objectives for the OTP, while the policy papers address particular fundamental issues on which the Office wants to provide more clarity and transparency. In accordance with OTP Regulation 14 (1), however, it appears that the OTP shall develop a Prosecutorial Strategy as the overall guidance. In our understanding, OTP Regulation 14 (1) refers to one coherent

\footnotetext{
${ }^{2}$ See also the Report on the activities during the first three years, 2006 [49].
} 
prosecution strategy in one master document. The current practice of strategies for timeframes of approximately three years does thus not comply with the wording of the mentioned Regulation. This is not just a formal point. To have one main document with the overall general or specific goals of a prosecution strategy indicates the general direction for the Office and this not only for the interested public but also for the personnel working in the Office. It is also more practical to have the overall strategy in one document instead of in various documents which are produced at different times and focus on different topics. Only a master document can set out a leitmotif from which focused strategies can be developed and on the basis of which periodic reflection can take place.

Three-year plans are valid as working agendas for the Office. They set out the strategy and goals for a specific period. Similarly, the policy papers reflect the strategic objectives and form the basis of the strategy. They are subject to unlimited revision due to their policy nature and do not give rise to any rights of litigation (Policy Paper on the Interests of Justice, at 1 [34]). On the basis of these papers and the work of the Court to date, the Prosecutor should draw lessons learned and set out a clearer strategy (in a similar vein HRW, 2011, at 2, 46 [26]; HRW, 2011, at 3-4 [25]). The OTP has commenced a transparent dialogue with external actors, which should be continued. In fact, the Prosecutor is well advised to increase this process of mutual exchange to further the ICC's credibility and to avoid the appearance of inconsistency of its selection decisions. For example, the Prosecutor should publish (as in fact foreseen by the Prosecutorial Strategy, 2009-2012 at 10 [45]), interim reports that terminate or enable the OTP to monitor preliminary examinations of certain country situations.

Transparency through interim reporting enhances the ICC's legitimacy. It will further contribute to the institutional development of the ICC and strengthen the hand of the new ICC Prosecutor elected by the end of 2011 (HRW, 2011, at 4 [25]). This lessonslearned process involves a two-pronged approach to be taken by the OTP: first, developing a newly-arranged strategy paper in accordance with OTP Regulation 14 (1), and, second, a continuation of the consultation process with external actors to design prosecutorial guidelines that cover the situation and case selection process and its criteria (thereto Stegmiller, 2011, at 268-9, [63]). Such guidelines would have to integrate the existing (draft) policy papers on the "interests of justice", preliminary examinations, case selection, etc., thus harmonizing the papers and consolidating the selection criteria in the form of policy-oriented guidelines.

\section{Focused investigations}

One guiding principle of the OTP is that of focused investigations and prosecutions. The Office has chosen to focus on the most serious crimes and on "those bearing the greatest responsibility". While the latter terminology allows for certain flexibility, the ICC Prosecutor mainly selects the persons from the top of the (state) hierarchy for his cases. Others are left to national criminal justice systems, encouraging territorial and third states to take measures against those offenders and to close the impunity gap (see Positive complementarity section for further understanding). In line with this focused approach the OTP has originally adopted a sequential approach, investigating cases within a situation one after another and selecting them according to their gravity (Report on Prosecutorial Strategy, 2006, at 5 [48]; for critique see HRW, 2006, at 5 
[23]; Ambos, 2010, at 38 [4]). Lately, the OTP has been more flexible in its approach and, for example in the Kenya proceedings, moved to simultaneous investigations, bringing two cases for prosecution at the same time (Case of the Prosecutor v. William Samoei Ruto, Henry Kiprono Kosgey and Joshua Arap Sang and the Case of the Prosecutor v. Francis Kirimi Muthaura, Uhuru Muigai Kenyatta and Mohammed Hussein Ali). Thus, while the OTP still mentions "focused investigations", the sequential approach is no longer explicitly contained in the Strategy 20092012 (at 10 [37]). This shows that certain flexibility is useful and that the Prosecutor must be able to adjust the strategy from time to time. Further, the Office's aim to shorten investigations and expedite trials is reflected in a selection of a limited number of the gravest incidents, representing the main types of victimization (Prosecutorial Strategy, 2010, at 6 [45]).

The focused approach adheres to practical realities and experiences from earlier international criminal trials. It is clearly impossible for the ICC to prosecute all potential perpetrators of international core crimes. The ensuing impunity gap can only be closed by prosecutions on the national level (Policy Paper, 2003, at 7 [33]). Thus, the success of the OTP's approach, with a view to the fight against impunity, depends on the strength of national systems and their integration into the international criminal justice system as a whole. On a different note, one must not confuse the OTP' policy choice to limit prosecutions to certain high caliber cases with the admissibility threshold as a legal barrier to bring certain cases (Rastan, 2010, at 97 [46]; Stegmiller, 2011 at 258, [63]). If the Prosecutor feels the need to take a broader approach, his policy may be adjusted accordingly, albeit always bearing in mind the need of coherence.

\section{The OTP's preliminary examination}

As stated at the beginning of this paper, the selection process of the OTP can be roughly divided into two stages: (i) the identification of situations, and (ii) the selection of cases. "Situations" refers to larger areas of conflict, in which the OTP investigates and builds up several case hypotheses. The situation selection is guided by the criteria of article 53 (1) ICC Statute, namely jurisdiction, admissibility and the "interests of justice" (Rules 48 and 104 RPE; further Stegmiller, 2011 at 209 et seq. [52]). Cases are selected according to similar legal criteria, either based on article 53 (2) ICC Statute or on a mutatis mutandis basis of article 53 (1) ICC Statute's factors. ${ }^{3}$

\footnotetext{
${ }^{3}$ According to OTP Regulation 33 the Prosecutor refers to the criteria of article 53 (1) ICC Statute regarding case selection, which seems to imply that article 53 (2) ICC Statute does not apply to case selection. Nevertheless, OTP Regulation 29 (5) mentions article 53 (2) in the context of prosecutions. As cases form the basis of a prosecution and are selected at a later stage, arising out of the specific situation, there is an argument that article 53 (2) covers case selection. Moreover, a limitation of article 53 (2) only to circumstances where the OTP decides to bring no prosecution at all in relation to a whole situation is not supported by literal and systematic interpretation: Article 53 (2) speaks of a "sufficient basis for prosecution", which is a higher standard than the one mentioned for situation selection ("reasonable basis") in Article 53 (1), and thus refers to a different stage. Systematically, both paragraphs 1 and 2 of article 53 are phrased in negative terms ("no" and "not"), but they do not indicate that they only cover negative decisions not to proceed. Notwithstanding the review mechanism under article 53 (3) solely covers negative decisions ("not to proceed") and the Chamber's intervention depends on such a case-specific decision of the Prosecutor. Otherwise, the carefully drafted review mechanism under article 53 (3) would be undermined. In other words, as long as a decision under article 53 (2) with regard to a particular suspect has not been issued by the OTP, it is not-existent and thus non-reviewable.
} 
Before dealing with the question of case selection, the OTP must traverse the preinvestigation stage, during which the examination and selection of situations for further investigations takes place. This preliminary examination stage is an important and necessary innovation compared to the pre-trial procedure of former International Criminal Tribunals (the International Military Tribunals in Nuremberg and Tokyo, the ICTY and ICTR, the Special Court for Sierra Leone, the Extraordinary Chambers in the Courts of Cambodia and the Special Tribunal for Lebanon). Contrary to these Ad Hoc International Criminal Tribunals that all possessed jurisdiction over a specific situation, limited in temporal and territorial terms, the ICC does not have such jurisdictional limitations (Draft Policy Paper on Preliminary Examinations, 2010, at 4 [15]). Instead, the ICC must pre-investigate and select its own situations. Even in the case of prima facie pre-defined situations, by way of a SC or State referral (see next section), the ultimate decision whether to initiate a formal investigation rests upon the Prosecutor and the Judges, based on the criteria of articles 53 (1) ICC Statute (Draft Policy Paper on Preliminary Examinations, 2010, at 5 [15]; Stegmiller, 2011 at 113-4, [63]).

\section{Overview of the process}

During the preliminary examination process the OTP assesses whether it opens a formal investigation into a situation. The analysis of a situation can be triggered through the following three mechanisms: (i) a State referral in accordance with articles 13 (a), 14 ICC Statute, (ii) a SC referral in accordance with article 13 (b) ICC Statute, or (iii) by proprio motu action of the Prosecutor on the basis of information received in accordance with articles 13 (c), 15 ICC Statute.

In general, all three trigger mechanisms are subject to the same analysis applying the same criteria. The initiation proprio motu only differs in two aspects: first, according to article 15 (3) ICC Statute the Prosecutor must submit a request for authorisation to the competent Pre-Trial Chamber, whereas in the case of referrals the Prosecutor can simply proceed with his formal investigation unless he determines that a reasonable basis does not exist (article 53 (1) ICC Statute); second, the assessment of information received under article 15 ICC Statute made it necessary to introduce a pre-filter mechanism. The "information received" (also referred to as "communications") shall be analyzed in accordance with article 15 (2) ICC Statute. This means that the information's "seriousness" is evaluated and crimes manifestly outside the ICC's jurisdiction are sorted out even before becoming formal "situations under analysis" (so called analysis phase 1, see Draft Policy Paper on Preliminary Examinations, 2010, at 18 [15]; HRW, 2011, at 4 [25]). The procedure under OTP Regulation 27 (a) arranges for an initial "pre-preliminary" check to filter out information that is unfounded on its face (according to the ICC website, by the end of May 20114,316 of a total of 9,214 communications received were considered "manifestly outside of the jurisdiction of the Court"; for an earlier report see Update on Communications, 2006, at 2-3 [64]). In any case, the "seriousness" filter is also applied to (State or Security Council) referrals (see Rule 104 (1) of the Rules of Procedure and Evidence [RPE]). In fact, it is a procedural filtering mechanism invented by the OTP to manage the large quantity of information about possible crimes it receives.

In the following preliminary analysis, the OTP evaluates the criteria set out in article 53 (1) ICC Statute, namely jurisdictional issues, admissibility and the interests 
of justice. In the first years of the ICC, the OTP distinguished three analysis phases: (i) Phase I - Initial Review; (ii) Phase II - Jurisdiction and Admissibility Assessment; and (iii) Phase III - Advanced Analysis and Planning (Annex to the Policy Paper, 2003 [7]; Stegmiller, 2011 at 215 et seq. [63]). The working method of the OTP has recently been refined and the components of phase II have been re-regrouped in the new phases two (jurisdiction), three (admissibility) and four (interests of justice), while giving up the former phase of advanced analysis and planning (Draft Policy Paper on Preliminary Examinations, 2010, at 18 [15]).

The differentiation of phases during the preliminary examination process was not foreseen by the ICC Statute and merely circumscribes the OTP's working process. On a statutory basis, two steps are distinguishable, which the OTP now clearly identified: first, article 15 (2) ICC Statute allows for an analysis of the "seriousness" of information received in order to identify communications that manifestly do not provide any basis for further action (see also RPE 104 (1). Second, the "reasonable basis" standard and the evaluation criteria must be examined. With regard to the three trigger possibilities mentioned above, it is most important to note that "reasonable basis" is applied in the same manner to all triggers according to articles 15 (3), (4), 53 ICC Statute, rules 48 and 104 of the ICC Rules of Procedure and Evidence (Stegmiller, 2011 at 213 [63]; Situation in Kenya, Decision pursuant to article 15 of the Rome Statute on the authorisation of an investigation into the situation in the Republic of Kenya, 31.3.2010, paras. 17 et seq. [57]). Jurisdiction, admissibility and interests of justice are thus the central criteria for the analysis and selections of situations.

\section{Critical evaluation of the draft policy paper on preliminary examinations}

The question of selecting situations and cases we apparent from the very beginning of the Court's work. Yet, in this starting phase practical necessities and administrative issues were on the top of the agenda rather than the development of a clear selection strategy. Furthermore, the situations of Uganda and the Democratic Republic of Congo (DRC), the first ones referred to the ICC in 2004 by the respective governments, were plainly of such gravity that a detailed weighting procedure did not yet present itself as a necessity. Only when the number of communications on potential situations increased, a policy with regard to preliminary examinations became a matter of urgency. At present, seven situations are under preliminary analysis (Colombia, Afghanistan, Georgia, Guinea, Honduras, Korea and Nigeria), and the OTP recently requested authorisation of an investigation regarding the Ivory Coast (Situation in the Republic of Côte d'Ivoire, Request for authorisation of an investigation pursuant to article 15, 23.06.2011 [58]), making it the second proprio motu request besides the situation in Kenya.

In October 2010 the OTP published a Draft Policy Paper on Preliminary Examinations which was widely circulated and invited critical commentary. This Preliminary Examinations Paper is largely based on an earlier (internal) draft paper on situation and case selection of 2006, which was also circulated, albeit not that widely, for comments among (external) experts. Other papers on key issues, such as case selection and positive complementarity, are still in the internal consultation process and have not yet been made available to the public. While it is certainly a major 
improvement, compared to the ad hoc tribunals, that the OTP interacts with NGOs and external experts, one wonders why the process of completing policy papers takes such a long time. Since early 2006 the OTP has been working on the strategic questions and postponed publication of those papers several times. From an outsider's perspective one can only speculate as to why the remaining papers have not been finalised. Give the increased activity of the Office, not least because of the (unexpected) SC referrals in the case of Sudan (Darfur) and Libya, it is quite likely that there are serious capacity problems. While there is no unit that deals exclusively with strategy or policy papers, most of the staff at the OTP are engaged in the pending situations and cases which involve complex, often new procedural questions which require priority treatment. Numerous legal challenges arise during on-going trial proceedings and deadlines pressure the OTP to find quick answers. Still, one wonders why the policy and strategy papers cannot be produced by the Chief Prosecutor and his immediate team, recently considerably reinforced by the appointment of additional advisors. ${ }^{4}$ These advisors are not involved in the daily work of the Office and their function is, if any, to help the Prosecutor to develop a coherent strategy and policy. In any case, a transparent selection process is important for the future of the ICC and could save working capacity. It is also crucial for the common acceptance of the Court. Strategic questions must be prioritized and solved as soon as possible. The election of a new Chief Prosecutor in December of last year and her taking over by mid 2012 allows for a fresh start learning the necessary lessons from the various missteps and failures of the predecessor (Kaye (2011), at 118 et seq. [28]). The new Prosecutor should as one of his/her first actions clarify the overall strategy. Working groups should be formed to tackle this important issue, involving external experts. The selection strategy affects the ICC as a whole and shapes its future.

With regard to the Paper on Preliminary Examinations, some explanations given by the OTP require further clarification. Take for example the non-existence of a definite time period for the completion of a preliminary examination (Draft Policy Paper on Preliminary Examinations, 2010, at 17 [15]). While fixed time limits may prove too rigid in light of the complexity of investigations of macrocriminality, the complete absence of any rule and the lack of external control of the preliminary examinations creates legal insecurity and gives rise to tension between the state concerned, the OTP and victims. After all, international human rights law demands a speedy process and this also in relation to the investigation phase. Thus, with regard to the situation in the Central African Republic (CAR) controversy arose between the OTP and the Pre-Trial Chamber concerning the status of the situation since the OTP provided no information for more than two years. To avoid such altercation in the future, the Chambers should be entitled to request status information after a certain time of inaction, carefully balancing prosecutorial independence against necessary checks by the Chambers (for a new rule providing for a time period of 18 months Stegmiller, 2011, at 235, [63]).

\footnotetext{
${ }^{4}$ Special Advisor on Gender Crimes Prof. Catharine MacKinnon, Special Advisor on International Humanitarian Law Prof. Tim McCormack, Special Advisor on International Law Prof. José Alvarez, Special Advisor on Crime Prevention Prof. Juan Méndez, Special Council to the Prosecutor Benjamin Ferencz, and Consultant for the OTP Judge Baltasar Garzon (in the meantime in Colombia as advisor to the OAS mission MAPP-OEA). See also the debates by invited 'experts' at http://uclalawforum.com/.
} 
The incumbent Prosecutor also introduced a practice of inviting so-called selfreferrals, which, according to the OTP, was "explicitly contemplated during the negotiations in Rome" (Draft Policy Paper on Preliminary Examinations, 2010, at 16 [15]). It is, however, controversial if the "idea that a State might refer a situation against itself was ever contemplated" (Schabas, 2010, at 309-10 [53]); in any case, the wording of Art. 13 (a), 14 does not exclude this possibility (for a recent thorough analysis, including of the travaux Robinson, 2011, at 359 et seq. [51]). Moreover, the policy question whether such referrals are to be favored over the proprio motu trigger, which the OTP explicitly mentions in its policy paper with regard to DRC, Uganda and Kenya (Draft Policy Paper on Preliminary Examinations, 2010, at 16-7 [15]), is worth discussing. The Court is now working at full capacity and proprio motu investigations might be the better choice in some situations. The possibility of the perception of a biased Court conducting one-sided investigations must, however, not be underestimated. These denunciations can easily be propagated in communities where knowledge about the ICC is scarce; a self-referral policy facilitates the spreading of such rumors, although the subsequent case selection, prosecuting all sides of the conflict, may neutralize criticism. The OTP can also avoid or diminish criticism by its well-established outreach program, the re-definition of referred situations and by an increased use of the proprio motu power. The last-mentioned switch to the proprio motu mechanism could be facilitated by the pending situations of Kenya and Côte d'Ivoire that will necessarily entail the treatment and hopefully solution of some legal questions involved. Obviously, the decision whether proprio motu to be used as the OTP's last resort or as an equal and powerful trigger mechanism ultimately lies in the hands of the new Prosecutor.

\section{Case selection}

Within those chosen situations the OTP must select cases for further investigation and prosecution. The determination of a case involves the following steps: (i) selecting regions, (ii) selecting incidents, (iii) selecting groups, and (iv) selecting individual perpetrators (Stahn, 2009, at 249 [60]; HRW, 2006, at 4 et seq. [23]; see also Regulation 49 of the Regulations of the Court which give guidance on what type of information the OTP needs to gather in order to start an inquiry). The Prosecutor has decided to select cases inside a situation according to gravity and prosecute only those suspects who bear the greatest responsibility for the most serious crimes (Prosecutorial Strategy, 2009-2012, at 6 [45]). The OTP implements the last-mentioned criteria in a discretionary manner (Stahn, 2009, at 251, 263 [60]). If applied in such a manner, the two criteria - "gravity" and "those bearing the greatest responsibility" - must be linked to the statutory basis that provides for prosecutorial discretion, i.e., article 42 (1) in general and article 53 (2) (c) in particular, including the broad "interest of justice" clause (Stegmiller, 2011, at 332 et seq., 355, 425, 428 et seq. [63]).

\section{Gravity as a case selection criterion}

The OTP stated in its policy papers that gravity is at the very heart of its selection procedure. According to OTP Regulation 29 (2), the following factors are to be taken into account: (i) scale, (ii) nature, (iii) manner of commission, and (iv) impact. 
Before the adoption of the OTP Regulations, there had been an intense debate on the factors that should be taken into account when applying gravity. The Pre-Trial Chambers upheld the factors mentioned by the OTP and equally favoured a mixed qualitative-quantitative approach (Situation in Kenya, Decision pursuant to article 15 of the Rome Statute on the authorisation of an investigation into the situation in the Republic of Kenya, 31.3.2010, para. 62 [57]; Prosecutor v. Bahar Idriss Abu Garda, Decision on the Confirmation of Charges, 8.2.2010, para. 31 [37]). Prior to that, a very rigid interpretation of the gravity threshold by Pre-Trial Chambers I in the case against Lubanga and Ntaganda, establishing a legal threshold through a focus on senior leaders only (Prosecutor v. Lubanga, Decision on the Prosecutor's application for warrant of arrest, 10.2.2006, paras. 41 et seq. [39]), was reversed in appeal proceedings (Situation in DRC, Judgement on the Prosecutor's appeal against the decision of Pre-Trial Chamber I, 13.7.2006, paras. 1 et seq. [56]). In the Pre-Trial Chamber's view gravity is to be understood as a legal threshold limiting the admissibility of ICC cases to "senior leaders"; this, of course, seriously limits the scope of the Court's activities. Contrary to this view, we submit that gravity entails both a discretionary notion and a legal filter, the "senior leaders" focus belonging to the former concept of discretionary gravity. In any event, the floor for further legal arguments regarding gravity has been re-opened by the Appeals Chamber.

At present, despite this intense debate, the overall concept of gravity remains largely unclear (De Guzman, 2009, at 1401 et seq. [12]). In particular, it is unclear where the gravity determination can, in the Statute, be normatively grounded. For case selection, gravity could be taken into account under articles 53 (2) (b), 17 (d) ICC Statute and/or article 53 (2) (c) ICC Statute. Taking into account OTP Regulation 29 and the above-mentioned decision by Pre-Trial Chamber II in the Kenyan situation, it seems that the OTP and the Pre-Trial Chamber solely regard gravity as the second part of the admissibility test under article 17 (1) ICC Statute. The statutory basis would then be found in articles 53 (2) (b), 17 (1) (d) ICC Statute (Guariglia, 2009, at 213 [19]). However, the OTP's own understanding in its policy papers is different, suggesting a broader reading of gravity in the sense of a discretionary concept as mentioned above. In line with this understanding, Paul Seils, the former Head of the Situation Analysis Section of the OTP, argues that some form of discretion ("principle of opportunity") is taken into account when the Office reaches its gravity decision (Seils, 2010, at 73 et seq. [54]). The way gravity is applied by the OTP entails a relative assessment, comparing cases to one another and involving discretionary choices, thereby going beyond a purely legal determination. Such a discretionary approach differs from the legal (non-discretionary) determination of gravity under article 17 (1) (d) ICC Statute (Ambos, 2010, at 48-9 [4]). In our view, the OTP is not prevented by the law to use gravity in such a way, but the statutory basis for a discretionary understanding can be found in article 53 (2) (c) (not article 17) of the Statute. Therefore, if gravity is used by the Prosecutor as a case selection and prioritization factor, it should be labelled accordingly, i.e., the OTP must reveal whether it uses gravity as a legal minimum threshold under article 17 (1) (d) ICC Statute or as a case selection criterion that involves discretionary considerations. If the latter is the case, as it appears from the strategy and policy papers, the OTP's gravity determination is a matter of article 53 (2) (c) ICC Statute, subject to judicial control under article 53 (3) ICC Statute. As a consequence, any decision not to 
prosecute individuals based on discretionary determination of gravity - no matter whether the pending situation was triggered proprio motu, through a State referral or a Security Council referral - could be reviewed by the Chambers (Stegmiller, 2011, at 451 [63]). This clearly follows from the wording of article 53 (3) ICC Statute, although the ensuing power of the respective State or the Security Council to trigger such a review (pursuant to article 53 (3) (a)) gives rise to concerns for these parties normally decide according to political considerations. It is therefore to be welcomed that, under this provision, the Pre-Trial Chamber may only request the Prosecutor to "reconsider" his decision, i.e., the ultimate decision is with the OTP. ${ }^{5}$

\section{Those bearing the greatest responsibility}

During case selection another important aspect is the OTP's policy of focusing on those suspects who bear the greatest responsibility for the most serious crimes. The question of whom to prosecute is one that concerns international crimes equally because the number of potential perpetrators is so large that is practically impossible to put everyone on trial. The related issue of avoiding impunity and prosecutorial gaps will be addressed below as a matter of positive complementarity, while at this point the implementation of the OTP's policy of focused investigations will be discussed.

The term used by the OTP ("those who bear the greatest responsibility") cannot be found in the ICC Statute, but guidance is given in the Preamble and in articles 5 and 17 ICC Statute (Policy Paper, 2003, at 6-7 [33]). The Prosecutor himself understands the criterion as a policy matter (Policy Paper, 2003, at 7 [33]). If it were to be understood as an legal requirement, a defendant could bring a challenge that he/she is only a minor perpetrator and as such would not fall under the ratione personae jurisdiction of the ICC or that his/her case would be inadmissible (in a similar context, the SCSL rejected a jurisdictional barrier; see Prosecutor v. Brima, Kamara and Kanu, paras. 282 et seq. [38]). In early jurisprudence, Pre-Trial Chamber I decided that, contrary to the OTP's view, a perpetrator must be among the "senior leaders most responsible" in order to comply with the admissibility requirement under the gravity threshold of article 17 (1) (d) ICC Statute (Decision on the Prosecutor's application for warrant of arrest, article 58, 10.2.2006, para. 51 [44]). This interpretation significantly limited the ICC's jurisdictional reach and was therefore correctly revoked by the Appeals Chamber. According to its view the Pre-Trial Chamber's approach would hamper the deterrent effect of the Court and it lacks a statutory basis (Situation in DRC, Judgement on the Prosecutor's appeal against the decision of PreTrial Chamber I, 13.7.2006, paras. 75 et seq. [56]). Consequently, the criterion is of a purely policy nature and cannot constitute a legal obstacle to the prosecution of certain persons (Guariglia, 2009, at 215 [19]). According to the OTP it is not a strict and precise threshold, but could even be interpreted as flexible as to include suspects below high-ranking officers (HRW, Courting History, 2008, at 59 [24]).

Given this flexibility it becomes apparent that this criterion cannot be associated with (legal) gravity under article 53 (2) (b), 17 (1) (d) ICC Statute, but must be

\footnotetext{
${ }^{5}$ In contrast, a decision not to proceed in the "interests of justice" under article 53 (3) (b) ICC Statute must be confirmed by the Chamber.
} 
located elsewhere. Indeed, a leadership requirement has not been treated by the OTP as a pure gravity notion (Schabas, 2008, at 745 [52]), but is certainly linked to it. According to Rod Rastan gravity "may have a broader function in guiding the exercise of discretionary powers in order to identify and prioritize the selection of cases" (Rastan, 2010, at 97 [46]).

While a certain level of flexibility with regard to the rank and role of suspects to be prosecuted is essential not only for the already mentioned reasons of deterrence but probably even more for very practical reasons, the implicit prosecutorial discretion in prioritizing certain suspects over others requires justification and reasons in order not to appear completely arbitrary.

The OTP itself has not yet made public its interpretation of this policy threshold, although factors related to gravity, such as the "manner of commission", give some indications as to the policy. ${ }^{6}$ Nevertheless, the OTP has been very reluctant to link senior leadership to any statutory basis, except the very general reference to the preamble, articles 5 and 17 ICC Statute. In fact, the OTP claims always to have full discretion once the article 17 (1)(d) gravity threshold is passed but it should not be overlooked that article 53 (2) (c) ICC Statute provides for an adequate framework for the OTP's policy (Stegmiller, 2011, at 444, [63]). Article 53 (2) (c) ICC Statue comprises the three factors that are relevant for the adoption of a focus on those bearing the greatest responsibility: (i) discretion, (ii) gravity (as a policy matter), and (iii) the role in the alleged crime. The latter two factors are even explicitly mentioned in the relevant sub-paragraph of article 53 and cover the most important characteristics of the terminology used by the OTP: "those bearing the greatest responsibility" (= "role" in article 53 (2) (c)) for the "most serious crimes" (= "gravity" in article 53 (2) (c)). If the OTP combines these three factors, it can apply its policy focus accordingly and it finds a solid statutory basis for such a policy. The only argument that might speak against such a reading of article 53 (2) (c) ICC Statute - from an OTP perspective - is the fact that the Prosecutor cannot apply a free-standing discretionary policy, but is subject to checks and balances as envisaged by article 53 ICC Statute. In other words, the Prosecutor's choices might be reviewed by a Pre-Trial Chamber under article 53 (3) ICC Statute.

\section{Positive complementarity}

With regard to complementarity, the OTP correctly emphasises that the primary responsibility for conducting investigations and prosecutions rests with the territorial State (Report on Prosecutorial Strategy, 2006, at 5 [48]). The combination of the complementarity principle with the OTP's focus on the most responsible entails, however, the risk of impunity gaps if the territorial state, due to capacity or other problems, fails to bring those responsible for international crimes, but below the top level to justice.

\footnotetext{
${ }^{6}$ See the Draft Policy Paper on Preliminary Examinations, 2010, at 15 [15]: "The manner of commission of the crimes may be assessed in light of, inter alia, the means employed to execute the crime, the degree of participation and intent in its commission, the extent to which the crimes were systematic or result from a plan or organized policy or otherwise resulted from the abuse of power or official capacity, and elements of particular cruelty, including the vulnerability of the victims, any motives involving discrimination, or the use of rape and sexual violence as a means of destroying communities."
} 
Complementarity contains two conceptual approaches: (i) the admissibility principle that deals with competing jurisdictions, and (ii) a principle of burden sharing for the consensual distribution of caseloads (Rastan, 2010, at 83 [46]). Concerning the latter the OTP adopted a policy of coordinated action which has been labeled positive complementarity (Prosecutorial Strategy, 2009-2012, at 5 [45]; Rastan, 2010, at 112-3 [46]; Burke-White, 2008, at 61 et seq. [10]; Stahn, 2008, at 88 [59]; Pampalk/Knust, 2010, at 672-4 [32]). Positive complementarity rests, in the sense of the mentioned burden sharing, on a partnership-based approach (Stahn, 2008, at 93-4, 102 [59]). The ICC is not meant to "compete" with States for jurisdiction, but is guided by the principles of partnership and vigilance (Informal Expert Paper on Complementarity, 2003, at 3 [27]).

In practical terms, positive complementarity means that the Prosecutor will encourage proceedings at the national level rather than taking over a case himself. In other words, even if a case is admissible in terms of the complementarity test, i.e., the respective State is, in principle, either unwilling or unable to investigate and prosecute it (for more details see Introduction section), the Prosecutor might encourage this State to take own action with the assistance of the OTP, without being directly involved in capacity building (Prosecutorial Strategy, 2009-2012, at 5 [45]; also Stahn, 2011, at 192-3 [61]). However, this approach of constructive burden sharing has so far only been applied with a third state (namely Germany in the case of the prosecution of leading FDLR members, see Selection strategy at the ICC (OTP) section) but not yet with a territorial State. As to the situation of Libya, where the new State authorities claim that the national justice system is actively investigating the cases of Saif Al-Islam Gaddafi and Abdullah Al-Senussi, the ICC faces a dilemma. According to the official Libyan view, it must, in line with its positive complementarity approach, declare the cases inadmissible (Prosecutor v. Al-Islam Gaddafi and Abdullah Al-Senussi, paras. 3-4 [36]). However, the problem is that the ICC has not yet determined a firm strategy with respect to parallel proceedings at the national level and that the OTP's prosecutorial practice has been inconsistent (Stahn, 2012, at 332-3 [62]). While in some cases the Prosecutor gave priority to facilitating domestic proceedings (e.g. Colombia; cf. Ambos, 2010 [4]), regarding Libya it is apparently expected that it actively challenges admissibility. This makes plain that considerable uncertainties exist with regard to the determination of domestic investigations and prosecution strategies in line with the existing admissibility test (Stahn, 2012, at 335-6, 339-40 [62]). It remains to be seen to which extent the OTP applies positive complementarity in the future in light of the Libya experience. Of course, the deeper conceptual problems regarding the precise requirements of "positive complementarity" have to be clarified (Stahn, 2012, at 348 [62]). In any case, given the high caseload of the ICC, there is no alternative but to promote the exercise of domestic jurisdiction by way of positive complementarity. If the territorial State is not able or willing the ICC may also cooperate with third States.

\section{Territorial states}

A territorial State can render any ICC proceedings inadmissible if it complies with the requirements provided for by the complementarity principle. According to article 17 ICC Statute a three-pronged test applies: first, the Court examines whether the State has taken action at all (inactivity scenarios); second, the exceptions mentioned in 
articles 17 (1) (a) - (c), 20 (3) ICC Statute render a case inadmissible before the ICC, unless, third, the exception to the exception - the unwillingness/inability test applies (Ambos, 2010, at 55 [4]). While the OTP recognizes, in principle, transitional justice mechanisms applied at the national level (Rastan, 2010, at 115 [46]; Policy Paper on the Interests of Justice, at 7-8 [34])), it has failed to provide guidance as to how transitional justice mechanisms are in compliance with statutory demands (Stegmiller, 2011 at 379, [63]). The Prosecutor cannot leave the ambiguous matter of alternative mechanisms entirely to States, but is supposed to monitor any crimes that are not investigated and prosecuted as far as these are related to the concrete situation or cases under investigation (too demanding Hall, 2009, at 227-8 [21] calling for a general monitoring function of the OTP). It is therefore an important task to develop coherent guidelines that specify the requirements for genuine investigations/prosecutions in territorial States. The Prosecutor must re-evaluate his Policy Paper on the Interests of Justice and propose his understanding of transitional justice mechanisms vis-à-vis the ICC Statute. The adopted narrow interpretation and the application of the "interests of justice" as a last resort (cf. Policy Paper on the Interests of Justice, at 3 [34]) does not exempt the OTP from developing a comprehensive approach. Despite the fact that each case varies and thus a case-specific approach is required, it is feasible and essential for the future work of the ICC to provide guidance on transitional justice mechanisms. From our point of view, the principle of complementarity even obliges the Prosecutor to recommend a proper framework which then may be accepted or corrected by the ICC Judges in a concrete proceeding. Otherwise, the territorial State cannot comply with (positive) complementarity as it can never be sure when its efforts are sufficient or not. It could only establish a mechanism in advance and then seek complementarity testing, with a high risk of failing the OTP's ad hoc standard. Positive complementarity, however, requires a mutual course of action in good faith. The OTP must therefore engage in a debate on measures that satisfy the complementarity regime.

While the latter task falls primarily within the sphere of the Prosecutor, the reform efforts concerning capacity building in the affected State do not. It is certainly necessary to foster national action to close the impunity gap, but significant progress in strengthening national justice systems is still lacking. The ICC itself lacks resources to become involved in national capacity building. It can potentially assist the territorial States by relying on its networks of cooperation, sharing certain information and databases etc. (Prosecutorial Strategy, 2010, at 5 [45]). The responsibility for strengthening the rule of law by providing technical and judicial assistance currently rests upon the international community (Rastan, 2010, at 121-2 [46]). During the stocktaking at the Review Conference in Kampala, the Assembly of State Parties committed itself to becoming a facilitator regarding the issue of complementarity and the strengthening of domestic jurisdictions (Resolution RC/Res.1 Complementarity, paras. 9-10 [50]. In our view, the Assembly of State Parties and the more powerful ICC Member States must take their responsibility more seriously and assist postconflict States in their development of criminal justice capacity. While the ICC may leave cases in the hands of the territorial State based on positive complementarity, it cannot re-build this State's domestic judicial system.

These efforts notwithstanding, another key actor is the Security Council. It should not use the referral tool as an instrument to relieve pressure from itself. It has to 
"follow through" a referral, i.e., it has to actively support the ICC in the enforcement of the decisions resulting from the referral. Unfortunately, the current practice of the Security Council goes to the contrary leaving the Court alone once a referral has been made. This is most apparent in the case against Al Bashir who, far from being surrendered to the Court, instead contemplates his re-election and calls the charges against him "lies" and "fabrications" (BBC Hard Talk, 14 May 2011). Still worse, with regard to Muammar-al-Gaddafi, the same permanent Security Council members (France, UK and USA) which promoted the referral in the first place went on - before the final victory of the rebels - to initiate secret negotiations about a Gaddafi exit including an immunity deal (see Dicker, 2011 [14]; Ambos, 2011, at 6 [6]). All such political games undermine the credibility and legitimacy of the Court.

\section{Third states}

The international criminal justice system operates on three levels in the fight against impunity of international crimes: (i) the level of the territorial States exercising its territorial jurisdiction, (ii) the level of the ICC exercising supranational jurisdiction, and (iii) the level of third States exercising extra-territorial jurisdiction, normally pursuant to the principle of universal jurisdiction. Only a mutual burden sharing between these three levels may efficiently contribute to the closing of the existing impunity gaps.

In situations where the territorial State cannot fulfil its obligation to prosecute, the ICC or third States should take appropriate action. If a domestic justice system fails to hold perpetrators accountable due to unwillingness or inability, "the role of the international community becomes crucial" (Rastan, 2010, at 123 [46]). In this regard universal jurisdiction as a basis for third States to prosecute plays a significant role (Hall, 2010, at 201 [22]). The close cooperation between the ICC, Rwanda, France and Germany in the cases against those most responsible for crimes committed in Eastern Congo by the "Forces Démocratiques de Libération du Rwanda" (FDLR), resulting in three arrests, is a shining example for positive complementarity (Factsheet Situation in the DRC, Callixte Mbarusihmana, 2010, at 3 [16]). These FDLR members are being prosecuted before the ICC (Callixte Mbarusihmana) and before the German Higher Regional Court (Oberlandesgericht) of Stuttgart (Ignace Murwanashyaka and Straton Musoni). The OTP sees the legal basis for such an approach in the Preamble and article 93 (10) of the ICC Statute, as well as its policy of positive complementarity, and stressed that the DRC authorities have been inactive in relation to the investigations in the Kivu region (Prosecutor v. Mbarushimana, Prosecution's Submission on Jurisdiction, 14.10.2010, paras. 24-5 [43]).

The German authorities have conducted the trial against Murwanshayka and Musoni on the basis of universal jurisdiction as enshrined in $\S 1$ of the German Code of International Criminal Law (GCICL, Völkerstrafgesetzbuch). This is the first time that universal jurisdiction under $\S 1$ GCICL has actually been applied by German Courts. It should be noted that the Federal Prosecutor has previously used $\S 153 \mathrm{f}$ of the German Criminal Procedural Code (GCPC, Strafprozessordnung) in numerous cases, such as the one against Donald Rumsfeld, to suspend further proceedings (for an explanation of the relationship between $\S 1$ GCICL and $\S 153 \mathrm{f} \mathrm{GCPC}$ see Ambos, 2007, at 45 et seq. [1]; see also id., 2009, at 420 et seq. [3]). $§ 153 \mathrm{f}$ of the GCPC gives 
the Prosecution discretion whether or not to open a case based on universal jurisdiction, if certain conditions are fulfilled. The German Federal Prosecutor ceased its own preliminary investigations against Mbarushimana in accordance with $\S 153 \mathrm{f}$ (2) clause 1 no. 4 of the GCPC, which allows for a discontinuation if the offence is prosecuted by "an international court of justice or by a country on whose territory the offence was committed, a citizen of which is either suspected of the offence, or suffered injury as a result of the offence". Mbarushimana's Defence instantly brought challenges related to issues concerning complementarity, using the preliminary investigations and the decision to cease these measures by the German Federal Prosecutor as its legal footing against the admissibility of the case. Both challenges, (i) before the ICC, and (ii) before the German Federal Constitutional Court, were not successful, but are interesting to analyse against the background of article 17 ICC Statute and positive complementarity.

The Defence submitted to Pre-Trial Chamber I that information provided by the OTP under article 58 ICC Statute was incomplete and "prevented the Pre-Trial-Chamber from ruling on admissibility in such circumstances where the case would, undoubtedly, have been deemed inadmissible" (Prosecutor v. Mbarushimana, Defence Challenge to the Validity of the Arrest Warrant, 10.1.2011, para.16 [42]). In particular, the Defence argued that Mbarushimana was an actual suspect in criminal investigations in Germany as he was jointly investigated with Murwanshyaka, that such an investigation was still ongoing until the 3 December 2010 and that for these reasons genuine investigative proceedings in the sense of article 17 (1) (a) ICC Statute were being conducted in Germany at the date of issuance of the arrest warrant and would have rendered the case inadmissible (Prosecutor v. Mbarushimana, Defence Challenge to the Validity of the Arrest Warrant, 10.1.2011, paras. 9 et seq. [42]).

The Chamber dismissed the challenge because the arrest warrant was properly issued and the case had not been clearly inadmissible (Prosecutor v. Mbarushimana, Decision of the Defence Challenge to the Validity of the Arrest Warrant, 28.1.2011, paras. 10-1 [40]). The OTP thus succeeded with its submission that the arrest warrant was issued in accordance with article 58 and that the Office did not omit any information (Prosecutor v. Mbarushimana, Prosecution Reponse to the "Defence Challenge to the Validity of the Arrest Warrant", 27.1.2011, paras. 10 et seq. [41]). As a result, the Chamber did not even go into the merits of admissibility, but denied a profound analysis of the early arrest warrant stage. The admissibility evaluation will be undertaken at a later stage, although the Chamber's decision prima facie speaks in favour of admissibility, or at least against any apparent admissibility defects.

This notwithstanding, the Defence called into question whether investigations had already been undertaken by the German Federal Prosecutor in the sense of article 17 (1) (a) or (b) ICC Statute, which could render the case inadmissible at a later stage. As part of the forthcoming admissibility analysis, the case would then be inadmissible if "the case is being investigated by a State which has jurisdiction over it" or "has been investigated by a State which has jurisdiction over it and the State has decided not to prosecute the person concerned". The gist of the issue is whether article 17 (1) (a), (b) ICC Statute applies to third States at all. Only if this is answered in the affirmative, one would have to look at the nature of the proceedings in Germany. According to a literal interpretation, "a State which has jurisdiction" could also be a third State that exercises universal jurisdiction. In the context of the right to challenge admissibility 
under article 19 ICC Statute, Hall therefore includes those States that have provided their Courts with jurisdiction, even if based on universality, as long as they have established domestic jurisdiction (Hall, 2008, 649 [20]). Germany has implemented this jurisdictional basis in $\S 1$ of the GCICL and would therefore, if one follows Hall, qualify as a country with the right to challenge admissibility. However, this interpretation is, for policy and practical reasons, not convincing. While it is clear that the ICC's jurisdiction only operates complementary to national jurisdictions, article 17 (1) (a), (b) ICC Statute is primarily meant to encourage States with a close link to the crime scene to take action (Ambos, 2009, 477 [2]). A teleological reading of complementarity therefore links article 17 (1) ICC Statute to the territorial State and the home country of the perpetrator or the victim, as recently correctly held by the German Constitutional Court following the first author of this paper (BVerfGE 2 BvR 1/11, 1.3.2011, NStZ 2011, at 354, para. 12 [11]). A double complementarity, implying that the ICC's jurisdiction is also subsidiary to universal jurisdiction, goes beyond the envisaged approach of complementarity (Kreß, 2000, at 625 [30]; van Heeck, 2006, at 172 [65]). The ICC only has subsidiary jurisdiction if the relevant national jurisdiction is based on the links expressed by the principles of territoriality, (active) nationality and or protection. With regard to the case of Mbarushimana, German authorities echoed a similar understanding of article 17 ICC Statute, stating that the ICC is the adequate forum to deal with the case and that they will assist the OTP's investigation (Prosecutor v. Mbarushimana, Prosecution Response to the "Defence Challenge to the Validity of the Arrest Warrant", 27.1.2011, para. 17 [41]; BVerfGE 2 BvR 1/11, 1.3.2011, NStZ 2011, at 353-4, para. 7 [11]).

In sum, subsidiary universal jurisdiction may play a decisive role to close the impunity gap, but it should only be subsidiary, i.e., be invoked only in exceptional cases as ultimate last resort. Third States can only exercise universal jurisdiction if (i) States with a stronger nexus are unable or unwilling to investigate or prosecute, and (ii) the ICC does not exercise its jurisdiction (Kleffner, 2008, at 284 [29]). For the first time, the cooperation between the ICC and Germany has touched upon this dimension of article 17 ICC Statute. Most likely, the issue will be examined in more detail once the Chamber conducts its admissibility assessment. It is though submitted that the course of action taken by the OTP was in accordance with complementarity to the extent that universal jurisdiction does not lead to subsidiarity of ICC proceedings. If one does not follow this understanding of article 17 ("a State which has jurisdiction"), one might have to examine more closely the actions taken by the German Prosecution authorities with regard to Callixte Mbarushimana. Irrespective of these questions, the OTP's enhancement of positive complementarity and the division of labour between the ICC and (third) States is to be welcomed as a matter of a wise and realistic prosecutorial policy. Indeed, only the close interaction with third States enables the ICC to close the impunity gap. Only increased cooperation between the territorial State, third States and the ICC brings us closer to world-wide accountability.

\section{Addressing the interests of victims}

Another principle of the OTP's policy is that it will always take into account the interests of victims. The Prosecutor will seek their views during all stages of the 
proceedings, i.e. the preliminary examination, investigation, pre-trial, trial and reparation stage (Prosecutorial Strategy, 2010, at 6-7 [45]). This approach corresponds to OTP Regulation 16 which stipulates: "The Office shall, in coordination with the Victims Participation and Reparations Section (VPRS) of the Registry, as appropriate, seek and receive the views of the victims at all stages in order to be mindful of and take into account their interest." It is not yet an easy task to identify the needs of the victims and who speaks on behalf of victims (Bock, 2010, at 317 [9]). For this purpose, the OTP promotes direct interaction with victims and victims' associations (Policy Paper on Victims' Participation, 2010, at 1 [35]). Clearly the inclusion of victims' views in such strategies places the ICC and the OTP in a new, particular and innovative constellation.

In addition, victims may promote their interests themselves. Victims' participation is a statutory right, mainly grounded in article 68 (3) ICC Statute, but also in other provisions of the ICC's legal texts. It was an innovation of the ICC to grant victims a more active role in the proceedings (Bock, 2010, at 440 et seq. [9]). At the earliest stages of situation analysis victims may participate informally and pass information to the Prosecutor (Bock, 2010, at 277, 463 [9]). In contrast, article 68 (3) ICC Statute gives the victims a stronger, more formalized right to participate actively in proceedings if (i) the applicant qualifies as a victim under rule 85 of the Rules of Procedure and evidence, (ii) the applicant's personal interests are affected by legal or factual issues raised in the proceedings at hand (Situation in DRC, Judgement on Victim Participation, 19.12.2008, para. 45 [55]). The Appeal's Chamber further denied a general participatory right during investigations, which it deemed to be the exclusive province of the Prosecutor (Situation in DRC, Judgement on Victim Participation, 19.12.2008, paras. 51, 57-9 [55]; critically thereto Bock, 2010, at 453 et seq. [9]). Hence, the victims' rights of active participation have to be assessed on a case-by-case basis and do not apply during investigations. However, even the Appeals Chamber does not preclude victims' participation in judicial proceedings at the investigation stage of a situation (Situation in DRC, Judgement on Victim Participation, 19.12.2008, para. 57 [55] - see e.g. articles 56, 57 (3) ICC Statute).

Be that it may, the OTP is, in any case under various statutory obligations (articles 15 (3), 19 (3), 53 (1) (c) ICC Statute) to grant victims certain participatory rights through making representations, even during investigations, and to inform them of decisions accordingly (Bock, 2010, at 506 et seq. [9]). The OTP has acknowledged this responsibility and stated that it "ensures interaction through public notice of its preliminary examination and investigation activities" (Policy Paper on Victims' Participation, 2010, at 14 [35]). While the Prosecutor has continuously improved the providing of public information, especially through weekly updates on preliminary examinations on the ICC website, interim reporting can still be enhanced. It would be important to make the reports on the Office's assessment of article 53 ICC Statute available once the OTP dismisses a situation after preliminary inquiries. These reports could provide more insight for the victims and the interested public. Clearly such efforts to address victims and to include them in dialogue would be entirely undermined by a selection strategy which is felt to ignore them. 


\section{Maximising the impact: developing a coherent strategy at the ICC}

The last principle mentioned by the OTP is to maximize the impact of activities of the Office. Through monitoring of situations the Prosecutor seeks to deter future crimes (Prosecutorial Strategy, 2009-2012, at 7 [45]). Deterrence should be achieved through the creation and activities of the ICC, with the OTP being an important multiplier. During the first years of the ICC the Prosecutor has fulfilled some of his objectives. First of all, the Office is in place and functioning, investigating crimes world-wide. Such a watchdog function alone may, albeit difficult to empirically demonstrate, have a deterrent effect. It must not be overlooked though that the deterrence capacity of ICL and thus the ICC is generally seen critically in scholarly writings (see Francis/Francis (2010), at 58 et seq. [17]; Golash (2010), at 201 et seq. [18]; Mullins/Rothe (2010), at 776 et seq. [31]). In any event, clearly leaders cannot move as freely as without an ICC arrest warrant.

Other than that, the OTP has consistently improved its work through its own critical evaluation. However, the new Prosecutor should continue this initial work and intensify efforts with regard to the overall strategy. The OTP must, policy-wise, revisit goals and impact critically (Stahn, 2011, at 197 [61]). Many challenges await the next Prosecutor (Kaye (2011), at 123 et seq. [28]). In the past, the Prosecutors' selection choices have not always been consistent (HRW, 2011, at 8 [26]; HRW, 2011, at 3 [25]). For example, it seems that the OTP did not apply the abovementioned criteria of "gravity" and "those bearing the greatest responsibility" in a comprehensive manner. Transparency and public access also bear potential for improvement. The more information the OTP provides on its selection choices the better understandable they are. However, such an open approach requires a solid strategy, in legal and policy terms. Only if prosecutorial selection is based on welldefined criteria, the Prosecutor's decisions will find support and gain legitimacy. Otherwise, negative implications and questions about the credibility and consistency of the Prosecutor's selection process will follow suit. The OTP should therefore foster efforts to develop comprehensible guidelines. These could be based on a comparative study on selection and prioritization of international crimes at the international (ICTY, ICTR and hybrid courts) and national level (for an initial survey see Bergsmo, 2010 [8]). While it is indeed difficult to learn from national models for ordinary crimes and even find models for international crimes (cf. Ambos, 2011 [5]), the ICC as an international court must explain its choices and is under greater pressure to justify selectivity. At least, a new strategy document, integrating the existing policy and strategy papers as well as drawing lessons learned, should be drafted with more clarity and precision. With regard to selection criteria, the Office must take definite positions. Moreover, the OTP's strategy should ideally be part of a broader prosecution strategy with regard to international crimes, making it clear which cases are to be pursued by the ICC and which ones are to be left to domestic jurisdictions. The impunity gap may only be closed or at least diminished through a comprehensive, well coordinated strategy. In any event, questions of prosecutorial discretion with regard to case selection and potential constraints remain the most significant issues in the near future of international criminal justice (cf De Guzman/Schabas, at 10-1 [13]). The OTP has also come under criticism for the fact that some situations have 
been under analysis for several years without any tangible results (HRW, 2011, at 7 [25]). It replied that no specific timeline governs the preliminary examinations (Draft Policy Paper on Preliminary Examinations, 2010, para. 84 [15]). While this is formally true since no specific time-frame exists in the applicable law, as already discussed above (III $1 \mathrm{~b}$ )), and preliminary examinations are the domain of the Prosecutor, the possibility for the Pre-Trial Chamber to intervene - at least in the form of asking for information on the status of the situation - should be included in the RPE (Stegmiller, 2011, at 233 et seq. [63]).

In sum, the OTP's strategy is still a work in progress. Issues of major importance, such as case selection and positive complementarity, are in the internal queue waiting for attention. Once the respective papers are published, the general ideas of prosecutorial selection are known and can thus be subject to public scrutiny. Some prosecutorial questions have already been consolidated by the OTP, while others remain disputed. In particular, the gravity criterion is far from settled jurisprudence and requires fine-tuning (Stegmiller, 2011, at 329 et seq. [63]). The whole selection process must lead to equal choices. If need be, a review mechanism for the Chambers could be established. Hitherto, the possible inclusion of judicial control under article 53 (3) ICC Statute has been carefully avoided due to the undefined use of discretion.

Finally, the understanding of discretion will shape the future of Court, especially the interaction and allocation of powers between the Prosecutor and the Chambers. Applying discretion in the selection process is certainly the Prosecutor's domain. However, as we have explained above, the ICC Statute does not provide for unlimited, free-standing discretion. The carefully drafted provision, dealing with selection choices, is article 53 ICC Statute. The Prosecutor must therefore adhere to the criteria of this provision, in other words, issues of (discretionary) "gravity" and "those bearing the greatest responsibility" are a matter of article 53 (1) (c) and (2) (c) ICC Statute. As such, a limited review power of the Pre-Trial Chamber may be exercised. Only checks and balances between the Prosecutor and the Chambers as well as a transparent selection strategy can ensure coherence of the ICC's future practice.

Acknowledgments The authors thank Dr. Rod Rastan (ICC-OTP), Prof. Robert Cryer and Dr. Marianne Wade (both Birmingham) for very useful and productive comments as well as Ousman Njikam (ICTYChamber) for a critical revision of the text.

Open Access This article is distributed under the terms of the Creative Commons Attribution License which permits any use, distribution, and reproduction in any medium, provided the original author(s) and the source are credited.

\section{References}

1. Ambos, K. (2007). International Core Crimes, Universal Jurisdiction and $\S 153 f$ German Criminal Procedure Code: A Commentary on the Decisions of the Federal Prosecutor General and the Stuttgart Higher Regional Court in the Abu Ghraib/Rumsfeld Case. Criminal Law Forum, 18(1), 43-58.

2. Ambos, K. (2009a). § 1 VStGB, in: Münchner Kommentar, Strafgesetzbuch, Nebenstrafrecht III, Völkerstrafgesetzbuch, Wolfgang Joecks/Klaus Miebach (eds.), 461-485.

3. Ambos, K. (2009b). Prosecuting Guantánamo in Europe: Can and Shall the Masterminds of the "Torture Memos" Be Held Criminally Responsible on the Basis of Universal Jurisdiction? Case Western Reserve Journal of International Law, 42, 405-448. 
4. Ambos, K. (2010). The Colombian Peace Process and the Principle of Complementarity of the International Criminal Court.

5. Ambos, K. (ed.) (2011a). Selección y priorización como estrategia de persecución en los casos de crímenes internacionales, Un estudio comparado, http://www2.gtz.de/dokumente/bib-2011/giz20110145es-estrategia-persecucion.pdf. Accessed 25 August 2012.

6. Ambos, K. (2011b). Geben und Nehmen, Frankfurter Allgemeine Zeitung, 11 August 2011 (spanish version, inter alia, in El Mundo, Madrid, 23 August 2011, 15).

7. Annex to the Policy Paper: Referrals and Communications, September 2003, The Hague. http:// www.icc-cpi.int/Menus/ICC/Structure + of + the + Court/Office + of + the + Prosecutor/Policies + and +Strategies/. Accessed 25 August 2012.

8. Bergsmo, M. (2010). The Theme of Selection and Prioritization Criteria and Why it Is Relevant, in: FICHL Publication Series No. 4, Criteria for Prioritizing and Selecting Core International Crimes Cases, Morten Bergsmo (ed.), 7-14.

9. Bock, S. (2010). Das Opfer vor dem Internationalen Strafgerichtshof.

10. Burke-White, W. (2008). Implementing a Policy of Positive Complementarity in the Rome System of Jusitce. Criminal Law Forum, 19(1), 59-85.

11. BVerfGE 2 BvR 1/11, 1.3.2011, NStZ 2011, 353-354. http://www.bverfg.de/entscheidungen/ rk20110301_2bvr000111.html. Accessed 25 August 2012.

12. De Guzman, M. (2009). Gravity and the Legitimacy of the International Criminal Court. Fordham International Law Journal, 32, 1400-1464.

13. De Guzman, M., \& Schabas, W. (2011). Initiation of Investigations and Selection of Cases, in: International Criminal Procedure Expert Framework, Towards a Codification of General Rules and Principles of International Criminal Procedure, October 2011, 8-11.

14. Dicker, R. (2001). Handing Qaddafi a Get-Out-Of-Jail-Free Card, International Herald Tribune, 1 August 2011.

15. Draft Policy Paper on Preliminary Examinations, 4 October 2010, The Hague. http://www.icc-cpi.int/ Menus/ICC/Strucutre+ + of + the + Court/Office + of + the + Prosecutor/Policies + and + Strategies/. Accessed 25 August 2012.

16. Factsheet Situation in the DRC, Callixte Mbarushimana, Office of the Prosecutor, The Hague, 11 October 2010. http://www.icc-cpi.int/NR/rdonlyres/DEB862E4-1E38-4C6E-9197-2953EC6D7EC9/ 282525/FactsheetENG2.pdf. Accessed 25 August 2012.

17. Francis, L., \& Francis, J. (2010). International Criminal Courts, the Rule of Law, and the Prevention of Harm: Building Justice in Times if Injustice, in: International Criminal Law and Philosophy, Larry May/Zachary Hoskins (eds.), 58-72.

18. Golash, D. (2010). The Justification of Punishment in the International Context, in: International Criminal Law and Philosophy, Larry May/Zachary Hoskins (eds.), 201-223.

19. Guariglia, F. (2009). The selection of cases by the Office of the Prosecutor of the International Criminal Court, in: The Emerging Practice of the International Criminal Court, Carsten Stahn/Göran Sluiter (eds.), 209-217.

20. Hall, C. (2008). Article 19, in: Commentary on the Rome Statute of the International Criminal Court, Second Edition, Otto Triffterer (ed.), 637-667.

21. Hall, C. (2009). Developing and Implementing an Effective Positive Complementarity Prosecution Strategy, in: The Emerging Practice of the International Criminal Court, Carsten Stahn/Göran Sluiter (eds.), 219-228.

22. Hall, C. (2010). The Role of Universal Jurisdiction in the International Criminal Court System, in: FICHL Publication Series No. 7, Complementarity and the Exercise of Universal Jurisdiction for Core International Crimes, Morten Bergsmo (ed.), 201-245.

23. HRW, The Selection of Situations and Cases for Trial before the International Criminal Court, A Human Rights Watch Policy Paper, October 2006. http:/www.hrw.org/en/news/2006/10/26/selectionsituations-and-cases-trial-international-criminal-court. Accessed 25 August 2012.

24. HRW, Courting History, The Landmark International Criminal Court's First Years, 2008, http:// www.hrw.org/en/reports/2008/07/10/courting-history-0. Accessed 25 August 2012.

25. HRW, Course Correction: Recommendations to the ICC Prosecutor for a More Effective Approach to "Situations under Analysis", June 2011. http://www.hrw.org/en/news/2011/06/16/icc-course-correc tion. Accessed 25 August 2012.

26. HRW, Unfinished Business, Closing gaps in the Selection of ICC cases, 15 September 2011, http:// www.hrw.org/reports/2011/09/15/unfinished-business-0. Accessed 25 August 2012.

27. Informal Expert Paper: The Principle of Complementarity in Practice, Office of the Prosecutor, The Hague, 2003. http://www.icc-cpi.int/Menus/ICC/Structure+of+the+Court/Office+of+the+Prosecutor/ Network+with+Partners/. Accessed 25 August 2012. 
28. Kaye, D. (2011). Who's afraid of the International Criminal Court? Foreign Affairs, 2011, 118-129.

29. Kleffner, J. (2008). Complementarity in the Rome Statute and National Criminal Jurisdictions.

30. Kreß, K. (2000). Völkerstrafrecht in Deutschland, in: Neue Zeitschrift für Strafrecht, No.12, 617-626.

31. Mullins, C., \& Rothe, D. (2010). Ability of the International Criminal Court to Deter Violations of International Criminal Law. International Criminal Law Review, 10(5), 771-786.

32. Pampalk, M., \& Knust, N. (2010). Transitional Justice und Positive Komplementarität, in: Zeitschrift für Internationale Strafrechtsdogmatik No. 11, 669-675.

33. Paper on policy issues before the Office of the Prosecutor, September 2003, The Hague. http:// www.icc-cpi.int/Menus/ICC/Structure+of + the + Court/Office + of + the + Prosecutor/Policies + and +Strategies/. Accessed 25 August 2012.

34. Policy Paper on the Interests of Justice, September 2007, The Hague. http://www.icc-cpi.int/Menus/ ICC/Structure+of+the+Court/Office+of+the+Prosecutor/Policies+and+Strategies/. Accessed 25 August 2012.

35. Policy Paper on Victims, 12 April 2010, Office of the Prosecutor, The Hague. http://www.icc-cpi.int/ Menus/ICC/Structure+ + f + the + Court/Office + of + the+Prosecutor/Policies + and + Strategies/. Accessed 25 August 2012.

36. Prosecutor v. Al-Islam Gaddafi and Abdullah Al-Senussi, Application on behalf of the Government of Libya pursuant to Article 19 of the ICC Statute, 1.5.2012 (ICC-01/11-01/11-130).

37. Prosecutor v. Bahar Idriss Abu Garda, Decision on the Confirmation of Charges, 8.2.2010 (ICC-02/0502/09-243). http://www.icc-cpi.int/Menus/ICC/Situations+and+Cases/Cases/. Accessed 25 August 2012.

38. Prosecutor v. Brima, Kamara and Kanu (AFRC trial), 22.2.2008 (SCSL-04-16-A-675).

39. Prosecutor v. Lubanga, Decision on the Prosecutor's application for warrant of arrest, article 58, 10.2.2006 (ICC-01/04-01/06-8-US-Corr., reclassified as public pursuant to decision ICC-01/04-01/ 06-37). http://www.icc-cpi.int/Menus/ICC/Situations+and+Cases/Cases/. Accessed 25 August 2012.

40. Prosecutor v. Mbarushimana, Decision of the Defence Challenge to the Validity of the Arrest Warrant, 28.1.2011 (ICC-01/04-01/10-50). http://www.icc-cpi.int/Menus/ICC/Situations+and+Cases/Cases/. Accessed 25 August 2012.

41. Prosecutor v. Mbarushimana, Prosecution Response to the "Defence Challenge to the Validity of the Arrest Warrant”, 27.1.2011 (ICC-01/04-01/10-35). http://www.icc-cpi.int/Menus/ICC/Situations+and +Cases/Cases/. Accessed 25 August 2012.

42. Prosecutor v. Mbarushimana, Defence Challenge to the Validity of the Arrest Warrant, 10.1.2011 (ICC-01/04-01/10-32). http://www.icc-cpi.int/Menus/ICC/Situations+and+Cases/Cases/. Accessed 25 August 2012.

43. Prosecutor v. Mbarushimana, Prosecution's Submission on Jurisdiction, 14.10.2010 (ICC-01/04-01/1012). http://www.icc-cpi.int/Menus/ICC/Situations+and+Cases/Cases/. Accessed 25 August 2012.

44. Prosecutor v. Ntaganda, Decision on the Prosecutor's application for warrant of arrest, article 58, 10.2.2006 (ICC-01/04-02/06-20-Anx2). http://www.icc-cpi.int/Menus/ICC/Situations+and+Cases/ Cases/. Accessed 25 August 2012.

45. Prosecutorial Strategy, 2009-2012, 1 February 2010, The Hague. http://www.icc-cpi.int/Menus/ICC/ Strucutre+of + the + Court/Office+ + of + the+Prosecutor/. Accessed 25 August 2012.

46. Rastan, R. (2010). Complementarity: Contest or collaboration? in: FICHL Publication Series No. 7 , Complementarity and the Exercise of Universal Jurisdiction for Core International Crimes, Morten Bergsmo (ed.), 83-132.

47. Regulations of the Office of the Prosecutor, ICC-BD/05-01-09, Entry into force: 23. April 2009. http:// www.icc-cpi.int/Menus/ICC/Legal+Texts+Tooles/. Accessed 25 August 2012.

48. Report on Prosecutorial Strategy, 14 September 2006, The Hague. http://www.icc-cpi.int/Menus/ICC/ Strucutre+of + the + Court/Office+ + of + the + Prosecutor/Policies+and+Strategies/Report+on+Prosecutorial +Strategy.htm. Accessed 25 August 2012.

49. Report on the activities performed during the first three years (June 2003-June 2006), 12 September 2006, The Hague. http://www.icc-cpi.int/Menus/ICC/Structure+of+the+Court/Office+of+the +Prosecutor/Reports+and+Statements/. Accessed 25 August 2012.

50. Resolution RC/Res.1 Complementarity, ASP $9^{\text {th }}$ plenary meeting, 8 June 2010, http://www.icc-cpi.int/ Menus/ASP/ReviewConference/Stocktaking/. Accessed 25 August 2012.

51. Robinson, D. (2011). The Controversy over Territorial State Referrals and Reflections on ICL Disclosure. Journal of International Criminal Justice, 9(2), 355-384.

52. Schabas, W. (2008). Prosecutorial Discretion vs. Judicial Activism. Journal of International Criminal Justice, 6(4), 731-761.

53. Schabas, W. (2010). The International Criminal Court, A Commentary on the Rome Statute. 
54. Seils, P. (2010). The Selection and Prioritization of Cases by the Office of the Prosecutor of the International Criminal Court, in: FICHL Publication Series No. 4, Criteria for Prioritizing and Selecting Core International Crimes Cases, Morten Bergsmo (ed.), 69-78.

55. Situation in DRC, Judgement on Victim Participation in the investigation stage of the proceedings in the appeal of the OPCD against the decision of Pre-Trial Chamber I of 7 December 2007 and in the appeals of the OPCD and the Prosecutor against the decision of Pre-Trial Chamber I of 24 December 2007, 19.12.2008 (ICC-01/04-556). http://www.icc-cpi.int/Menus/ICC/Situations+and+Cases/Cases/. Accessed 25 August 2012.

56. Situation in DRC, Judgement on the Prosecutor's appeal against the decision of Pre-Trial Chamber I entitled "Decision on the Prosecutor's application for warrants of arrest, article 58", 13.7.2006 (ICC01/04-169). http://www.icc-cpi.int/Menus/ICC/Situations+and+Cases/Cases/. Accessed 25 August 2012.

57. Situation in Kenya, Decision pursuant to article 15 of the Rome Statute on the authorisation of an investigation into the situation in the Republic of Kenya, 31.3.2010 (ICC-01/09-19). http://www.icccpi.int/Menus/ICC/Situations+and+Cases/Cases/. Accessed 25 August 2012.

58. Situation in the Republic of Côte d'Ivoire, Request for authorisation of an investigation pursuant to article 15, 23.06.2011 (ICC-02/11-3). http://www.icc-cpi.int/Menus/ICC/Situations+and+Cases/Cases/. Accessed 25 August 2012.

59. Stahn, C. (2008). Complementarity: A Tale of Two Notions. Criminal Law Forum, 19(1), 87-113.

60. Stahn, C. (2009). Judicial review of prosecutorial discretion: Five years on, in: The Emerging Practice of the International Criminal Court, Carsten Stahn/Göran Sluiter (eds.), 247-279.

61. Stahn, C. (2011). How is the Water? Criminal Law Forum, 22(1-2), 175-197.

62. Stahn, C. (2012). Libya, the International Criminal Court and Complementarity. Journal of International Criminal Justice, 10, 325-349.

63. Stegmiller, I. (2011). The Pre-Investigation Stage of the ICC, Criteria for Situation Selection. Studies in International and European Criminal Law and Procedure, vol. 8.

64. Update on Communications Received by the Prosecutor of the ICC, 10 February 2006, The Hague. http://www.icc-cpi.int/Menus/ICC/Structure+of+the+Court/Office+of+the+Prosecutor/Reports+and +Statements/. Accessed 25 August 2012.

65. Van Heeck, S. (2006). Die Weiterentwicklung des formellen Völkerstrafrechts. 